\title{
Review of research to inform California's climate scoping plan: Agriculture and working lands
}

\author{
California's diverse agricultural systems offer a range of opportunities for reducing \\ climate-warming emissions.
}

by Ryan Byrnes, Valerie Eviner, Ermias Kebreab, William R. Horwath, Louise Jackson, Bryan M. Jenkins, Stephen Kaffka, Amber Kerr, Josette Lewis, Frank M. Mitloehner, Jeffrey P. Mitchell, Kate M. Scow, Kerri L. Steenwerth and Stephen Wheeler

\section{Abstract}

Agriculture in California contributes $8 \%$ of the state's greenhouse gas (GHG) emissions. To inform the state's policy and program strategy to meet climate targets, we review recent research on practices that can reduce emissions, sequester carbon and provide other co-benefits to producers and the environment across agriculture and rangeland systems. Importantly, the research reviewed here was conducted in California and addresses practices in our specific agricultural, socioeconomic and biophysical environment. Farmland conversion and the dairy and intensive livestock sector are the largest contributors to GHG emissions and offer the greatest opportunities for avoided emissions. We also identify a range of other opportunities including soil and nutrient management, integrated and diversified farming systems, rangeland management, and biomassbased energy generation. Additional research to replicate and quantify the emissions reduction or carbon sequestration potential of these practices will strengthen the evidence base for California climate policy.

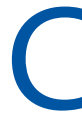
alifornia has committed to cutting greenhouse gas (GHG) emissions by $40 \%$ of 1990 levels by 2030. As a sector, agriculture is responsible for $8 \%$ of state emissions. Approximately two-thirds of that is from livestock production (manure management and enteric fermentation); $20 \%$ from fertilizer use and soil management associated with crop production; and $13 \%$ from fuel use associated with agricultural activities (e.g., irrigation pumping, cooling or heating commodities) (CARB 2017a). California plays an essential role in the nutritional quality of our national food system, accounting for, by value, roughly two-thirds of U.S. fruit and nut production, half of U.S. vegetable production and $20 \%$ of U.S. dairy production.

Assembly Bill 32, California's primary climate policy law, adopted in 2006, has spurred research into practices and technologies that could assist in reducing emissions and sequestering carbon. Here we report on

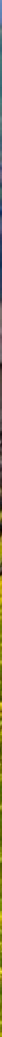


more than 50 California-based studies prompted by this landmark legislation. We note that the California Department of Food and Agriculture, California Air Resources Board, California Energy Commission and California Department of Water Resources have been critical to funding much of the science reviewed here. This article grew out of conversations with state agencies concerning the need for a review of the current evidence base to inform emissions-reduction modeling and revisions to the state Climate Change Scoping Plan (CARB 2017b), which specifies net emissions reduction targets for each major sector of the California economy (table 1). It is important to note that the Scoping Plan states that work will continue through 2017 to estimate the range of potential sequestration benefits from natural and working lands (including agriculture and rangelands).

With over 76,000 farm and ranch operations in California, covering about 30 million acres (USDA 2015), there are no one size fits all solutions. But as we outline below, there are numerous opportunities to both reduce GHG emissions and sequester carbon across diverse agricultural operations - small to large, organic and conventional, crop and livestock. Perhaps most importantly, many of these practices have cobenefits for water conservation, restoration and conservation of natural lands, or farm economics.

\section{Farmland and rangeland preservation}

Since 1984, farming and grazing lands have been converted to urban development at an average rate of 40,000 acres per year (DOC 2016). At this rate, and considering the higher rate of emissions from urban versus agricultural land, slowing agricultural land conversion represents one of the largest opportunities for agriculture to contribute to California's climate plan. Research from one county estimates that GHG emissions associated with urban landscapes are up to 70 times greater per acre than those from irrigated farmland when human emissions related to transportation, electricity, natural gas, and water are accounted for (Haden et al. 2013; Jackson et al. 2012). With continued population growth in the state, policies that promote more energy efficient patterns of urban development are critical to meeting climate targets and preserving irreplaceable farmland. Models show that coupling such urban development policies with farmland conservation could reduce transportation and buildingrelated emissions from new residential development by $50 \%$ by 2050 under a low-emissions scenario (Wheeler et al. 2013).

With $80 \%$ of California's most productive rangeland privately owned, losses are projected at 750,000 acres by 2040 (Cameron et al. 2014). Conversion of rangeland to urban uses may increase GHG emissions up to 100-fold depending on how the rangeland is managed, and conversion to irrigated agriculture may lead to increases of up to 2.5-fold (Haden et al. 2013).

Land-use-related policies to reduce GHG emissions in California are still at an early stage. Several new incentive programs warrant future research to optimize their impact. These include the Sustainable Agricultural Lands Conservation Program (SALC), for purchase of conservation easements on farmland at risk of suburban sprawl development; the Affordable Housing and Sustainable Communities Program (AHSC), supporting development of affordable housing within existing urban areas; and the Transformative Climate Communities Program (TCC), slated to provide GHG-reducing planning grants to disadvantaged communities beginning in 2017. Together with legislation requiring a regional Sustainable Community Strategy, these can create a land use planning framework in California to preserve farmland, reduce GHG emissions, and achieve other co-benefits such as improved quality of life, public health and social equity.

\section{Soil and nutrient management}

Soils are complex biological systems that provide ecosystem services and can be managed to store carbon, reduce emissions and provide environmental and economic co-benefits. The diversity of California agriculture requires different management strategies to mitigate GHG emissions or sequester carbon.

Soil GHG emissions increase with soil moisture and nutrient availability. Significant reductions in GHG emissions can be achieved by shifting management practices to more efficient irrigation and fertigation

TABLE 1. GHG emissions targets per the 2017 Climate Change Scoping Plan update

\begin{tabular}{|c|c|c|c|}
\hline & \multicolumn{3}{|c|}{ Estimated GHGs by sector $\left(\mathrm{MMTCO}_{2} \mathrm{e}\right)$} \\
\hline & 1990 & $\begin{array}{l}2030 \text { Proposed } \\
\text { plan ranges }\end{array}$ & $\begin{array}{l}\% \text { Change } \\
\text { from } 1990\end{array}$ \\
\hline Agriculture & 26 & $24-25$ & -4 to -8 \\
\hline Residential and commercial & 44 & $38-40$ & -9 to -14 \\
\hline Electric power & 108 & $42-62$ & -43 to -61 \\
\hline High GWP gases* & 3 & $8-11$ & 167 to 267 \\
\hline Industrial & 98 & $77-87$ & -11 to -21 \\
\hline Recycling and waste & 7 & $8-9$ & 14 to 29 \\
\hline Transportation $†$ & 152 & $103-111$ & -27 to -32 \\
\hline Net carbon sink — landscapes $\ddagger$ & -7 & TBD & TBD \\
\hline Subtotal & 431 & $300-345$ & -20 to -30 \\
\hline Cap-and-trade program & $\mathrm{n} / \mathrm{a}$ & $40-85$ & $\mathrm{n} / \mathrm{a}$ \\
\hline Total & 431 & 260 & -40 \\
\hline \multicolumn{4}{|c|}{$\begin{array}{l}\text { Source: CARB 2017b, Table II-3. Figures shown for } 2030 \text { for each sector represent expected changes in emissions under existin } \\
\text { state policies. The cap-and-trade program is a market mechanism designed to efficiently drive the additional emissions } \\
\text { reductions needed to reach the } 2030 \text { target. See www.arb.ca.gov/cc/cc.htm. }\end{array}$} \\
\hline \multicolumn{4}{|c|}{$\begin{array}{l}\text { * These are gases such as refrigerants that, per unit, have a much more potent warming effect than carbon dioxide (GWP = } \\
\text { global warming potential). }\end{array}$} \\
\hline \multicolumn{4}{|c|}{ † Includes the freight, communications and utilities sectors. } \\
\hline $\begin{array}{l}\text { \# Refers to the potential for carbon seque } \\
\text { lands. The potential magnitude of this }\end{array}$ & ing la & $\mathrm{ms}$, ranches and $\mathrm{n}$ & rests) and natura \\
\hline
\end{tabular}


A no-till field with residue from a winter crop of triticale. Management practices can increase total soil carbon, but the magnitude and persistence of sequestration is dependent on inputs and time. systems such as micro-irrigation and subsurface drip. A comparison of subsurface drip versus furrow irrigation showed decreased GHG emissions in the former (Kallenbach et al. 2010; Kennedy et al. 2013). While cover crops often increase GHG emissions, integrating more efficient irrigation with cover crop practices decreased nitrous oxide emissions two- to three-fold in California processing tomatoes (Kallenbach et al. 2010; Kennedy et al. 2013).

In semi-arid regions such as California, the longterm implementation of no-till practices reduced emissions by $14 \%$ to $34 \%$, but only after 10 years of continuous management. Under shorter time horizons, emissions increased by up to $38 \%$ (Six et al. 2004; van Kessel et al. 2013). Socioeconomic and biophysical limitations unique to California have led to low no-till adoption rates in California of roughly 2\% (Mitchell et al. 2009).

Improved nitrogen management provides a high potential for reductions in emissions, including emissions associated with applied fertilizer as well as emissions related to the production and transport of inorganic nitrogen fertilizer (Steenwerth et al. 2015). $\mathrm{N}_{2} \mathrm{O}$ emissions respond linearly to fertilizer application in lettuce, tomato, wine grape and wheat systems in California (Burger et al. 2012). However, once fertilizer rate exceeds crop demand, emissions increase at a logarithmic rate (McSwiney et al. 2005).

Fertilizer source has been broadly shown to influence $\mathrm{N}_{2} \mathrm{O}$ emissions (Burger et al. 2011). Only a few California studies compare synthetic fertilizer sources. One shows that ammonium sulfate reduced $\mathrm{N}_{2} \mathrm{O}$ emissions approximately 0.24 to $2.2 \mathrm{~kg} \mathrm{~N}$ per acre compared

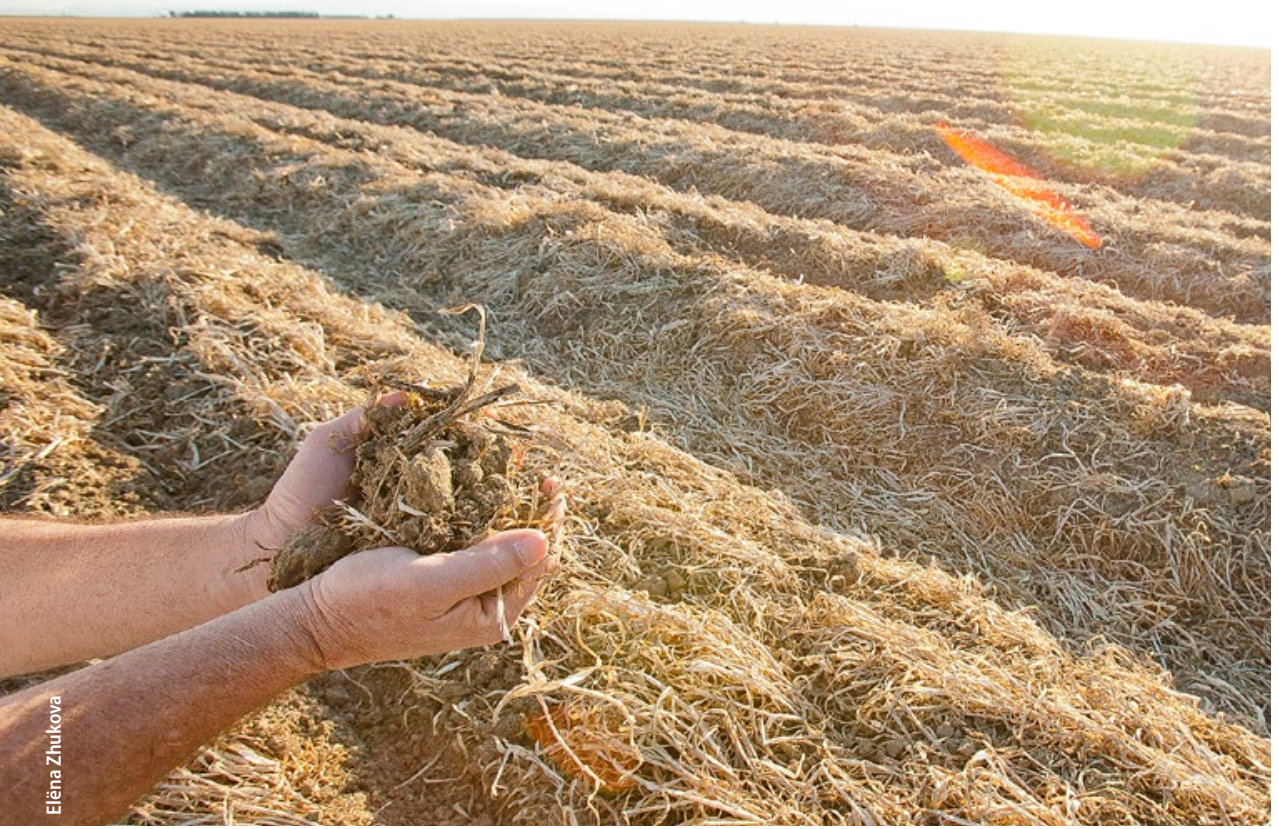

to aqua ammonium (Zhu-Barker et al. 2015a). Another study of comparing fertilizer sources found emissions reductions of up to 34\% (Brown and Muhammad 2011; Schellenberg et al. 2012); however, the results were not statistically significant. Recently, California research has shown that the use of manure and green waste fertilizers can increase emissions when applied to the soil surface (Zhu-Barker et al. 2015b), particularly if their use is not timed to crop demand (Lazcano et al. 2016). Fertilizer source and timing, along with the use of nitrification inhibitors, are key areas for future research in the California context.

Management practices have the potential to increase total soil carbon, but the magnitude and persistence of sequestration is dependent on inputs and time. In grasslands, pilot studies of carbon sequestration associated with compost application are being conducted to validate early findings throughout the state (see "Rangeland management" section below). For cultivated systems, in two long-term projects at UC Davis, soil carbon increased 1.4 and 2.3 tons per acre in the top 12 inches of soil over 10 years $(0.14$ and 0.23 tons per acre per year) in cover cropped and organically managed soil, respectively (Poudel et al. 2002). In an ongoing experiment at the UC Agriculture and Natural Resources West Side Research and Extension Center, no-till combined with cover cropping and standard agronomic practice in a tomato-cotton rotation system has increased soil carbon 5.3 tons per acre over 15 years ( 0.3 tons per acre per year) compared to the standard tillage, no cover crop treatment (Mitchell et al. 2017).

In these two long-term studies, the soil carbon increase occurred between 5 and 10 years. However, when cover cropping and compost inputs were ceased at the first site (Poudel et al. 2002), it led to a rapid loss of soil carbon. This shows that soil carbon sequestration is highly dependent on annual carbon inputs and if management changes, soil carbon is prone to return to the atmosphere.

Given the reality of inconsistent management, rates of soil carbon sequestration that can be expected in row crop systems practice are perhaps $10 \%$ of the values seen in these long-term research trials, namely in the range of 0.014 to 0.03 tons per acre per year (unpublished data). If soil carbon sequestration and storage are priorities, management plans and incentive structures should account for the wide variability of California soils and the need for consistent management over time.

While any single soil and nutrient management practice may have limited impact on GHG emissions, many have well-documented co-benefits, including reductions in erosion, improved air quality (Madden et al. 2008), reduced farm machinery fossil fuel use (West et al. 2002), reduced nitrogen leaching (Poudel et al. 2002), enhanced water infiltration and reduced soil water evaporation (Mitchell 2012), and increased carbon stocks below the root zone to improve carbon sequestration (Suddick et al. 2013). 


\section{Integrated and diversified farming systems}

Integrated or diversified farming systems are multipurpose operations that may produce several commodities and utilize renewable resources. Examples include integrated crop and livestock systems; organic production; orchard and annual crop intercropping; use of perennial, salt-tolerant grasses irrigated with saline drainage water on otherwise marginal land; and pastures improved by seeding beneficial plants such as legumes. Through reliance on biological processes to build healthy soils and support above and below ground biodiversity, diversified systems offer potential GHG emission reductions (through, for instance, application of on-farm sources of organic matter residues from plants and animals rather than fossil fuel-based fertilizers, carbon storage in woody plants, and more efficiency in nutrient management due to crop rotations). Also, resilience to climate perturbations can occur by spreading economic risks across multiple farm products (Jackson et al. 2011) and by relying on on-farm resources and biodiversity, with less dependence on synthetic fertilizer and pesticides to improve soil and crop health (Gurr et al. 2003; Hodson and Lewis 2016; Suddick et al. 2010). Other environmental co-benefits can include more efficient use of water, improved water and soil quality, pest reduction or suppression, or enhancement of wildlife habitat and biodiversity.

These systems have been shown to reduce soil nitrate and nitrous oxide emissions, and increase carbon sequestration both in soils and above ground biomass (Bowles et al. 2015; Garland et al. 2011; Smukler et al. 2010, 2011; Williams et al. 2011). For example, frequent addition of various types of organic inputs increases labile and resistant soil carbon over a period of several years, so that soils exhibit more tightly coupled plantsoil nitrogen cycling. In turn, plant nitrogen demand is adequately met, but losses of nitrate are minimized (Bowles et al. 2015). In another case, an organic vegetable production system, the annual use of cover crops over 6 years led to greater increases in microbial biomass carbon pools, and compost additions increased measured soil organic carbon pool and microbial diversity in comparison to a cover crop grown every fourth year (Brennan and Acosta-Martinez 2017). Many of these studies examined California organic farms where multiple practices are often stacked, such as combining organic soil amendments, integrating cover crops into crop rotation for year-round plant cover and reducing tillage. In addition, farmscaping with perennials on field margins and maintenance of vegetated riparian corridors sequester carbon in the soil and woody biomass of trees and shrubs (Hodson et al. 2014; Smukler et al. 2010). Planting native woody species tolerant of drought for hedgerows, or resistant to water flux in riparian corridors, is a way to ensure adaptation and growth over many decades. Use of tailwater ponds and sediment traps also plays an important role in soil and water quality (Smukler et al. 2011).

Diversified, multipurpose systems provide other co-benefits depending on the set of practices involved. Practices that increase soil carbon also improve soil structure, nitrogen-supplying power and water-holding capacity (Burger et al. 2005). For example, a practice like cover cropping also can suppress weeds, influence crop nutrition and quality, especially in perennial systems like wine grapes, and provide habitat for beneficial predators (Guerra and Steenwerth 2011). Filter strips and riparian corridors can reduce soil erosion and thereby diminish contamination of surface water with valuable soil and nutrient resources, and pathogenic microbes (Tate et al. 2006). Hedgerows have been shown to increase pollinators and other beneficial insects in California (Morandin et al. 2011; Ponisio et al. 2015). Given the promise for multiple co-benefits, more types of California diversified systems deserve study, which would provide a better basis for metrics to evaluate their long-term contributions to climate and other goals.

\section{Dairy and intensive livestock}

Intensive livestock operations, particularly the state's large dairy sector, produce two-thirds of California's agricultural GHG emissions, and thus are a primary target for state climate regulations as well as incentives for emission reduction. At the same time, policies should account for the already high levels of resource efficiency in the California dairy sector. A key climate policy concept is to avoid "leakage," whereby strict climate policy to reduce emissions in one region causes increases in another. A recent comparison of the dairy sectors of the Netherlands, California and New Zealand documents that California dairies on average produce more milk

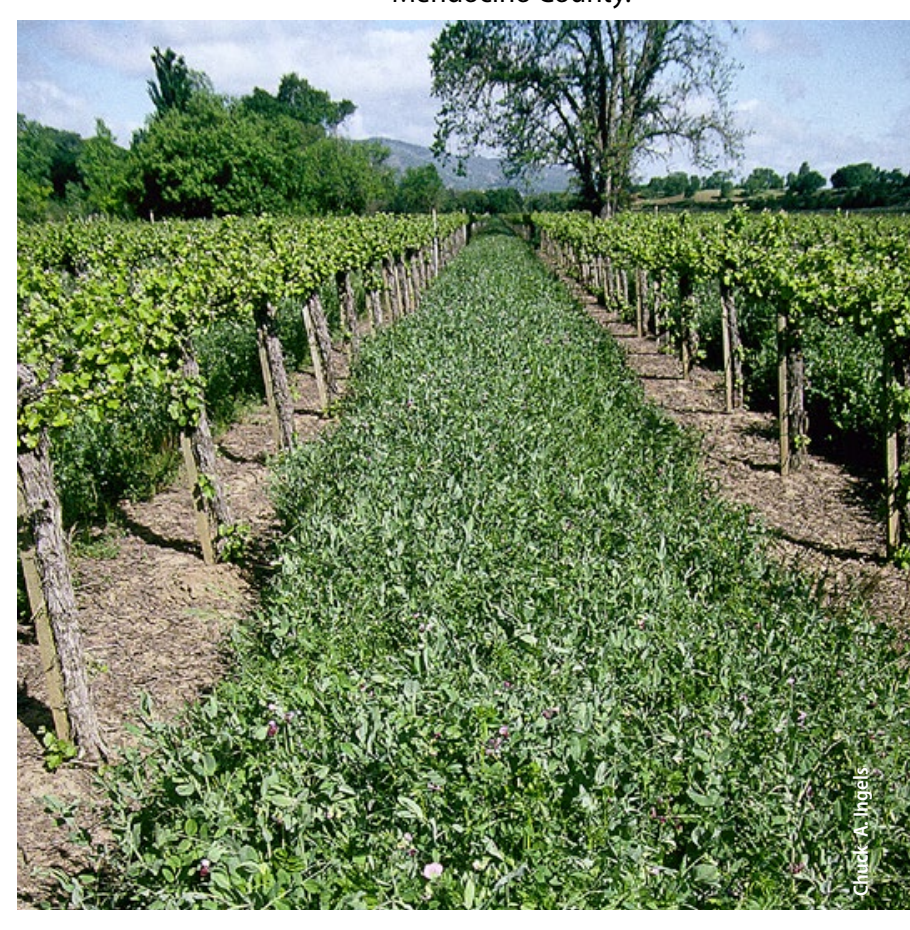
per cow than dairies in the Netherlands, and more than 2.6 times as much as dairies in New Zealand, while operating under stricter environmental regulations (Rabobank 2014).

Currently, the Intergovernmental Panel on Climate Change (IPCC) recommends using a fixed emission factor for dairy operations that is based on gross energy intake, which does not take diet composition into consideration (IPCC 2006). Calibration of GHG models
A vetch-pea cover crop in Mendocino County. 
lagoon storage systems, which can emit large amounts of methane, lend themselves to the use of covers or engineered anaerobic digestion systems for bio-methane collection. Potential trade-offs of these practices with respect to air quality, crop management, nutrient use efficiency and cost, however, require further analysis. Pasture systems are used in coastal areas where farms have less crop land available than in the Central Valley; pasture requires significantly more land and water for feed production compared to current dairy systems that rely on corn silage, grass silage and alfalfa (CARB 2016).

\section{Rangeland management}

Comprising more than two-thirds of California's agricultural acreage (USDA 2015), these working lands provide ecosystem services in addition to supporting production of livestock. Grasslands have higher levels of total soil carbon compared to cultivated lands (Steenwerth et al. 2005), and similar amounts to California forests.

There are numerous options for increasing carbon storage in rangelands. Modeling analyses project that restoration of native oaks could increase carbon storage in wood biomass and litter (Kroeger et al. 2009). In a study of riparian revegetation in Marin, Sonoma and Napa counties, modeled soil carbon sequestration rates averaged 0.8 tons $\mathrm{C}$ per acre per year, while modeled results of restored woody riparian areas demonstrated ecosystem carbon storage potential (soil plus woody biomass) of 16.4 tons $C$ per acre per year over a 45 -year period (Lewis et al. 2015). Cultivation and re-seeding to restore native perennial grasses also shows promise. Native grasses may sequester carbon in slightly deeper soil levels due to perennial root systems (Potthoff et al. 2009; Steenwerth et al. 2002). Rangelands with native grasses and oaks have lower soil carbon losses (Koteen et al. 2011) and higher nitrogen cycling rates (Parker et al. 2009)
Approaches to verifying carbon sequestration on rangelands requires a long-term approach. Soil carbon can take decades to build to a measurable level: rangelands rarely receive intensive management and these systems are much more exposed than irrigated agriculture to annual variations in moisture. On average, California's grasslands lose carbon, but the net $\mathrm{C}$ gain or loss depends on precipitation, with net losses of carbon in years when the timing of precipitation causes a short growing season, and gains when the timing of rains lead to a longer growing season (Ma et al. 2007).

The use of composted materials in rangelands may reduce $\mathrm{N}_{2} \mathrm{O}$ emissions in comparison to those materials entering waste streams and being subject to the standard manure and green waste management practices (Ryals et al. 2013; DeLonge et al. 2013). One study on California's coastal and valley grasslands showed that use of compost above standard application rates could boost net ecosystem carbon by $25 \%$ to $70 \%$, sequestering carbon at a rate of 0.2063 tons $C$ to 0.2104 tons $C$ per acre over the 3 -year study or a rate of 0.0688 tons $C$ to 0.0701 tons $\mathrm{C}$ per acre per year, largely by decreasing the amount of $\mathrm{C}$ that is being lost from these grasslands (Ryals et al. 2013). Researchers using the DAYCENT model to look at different compost amendments and project over longer time frames found that the net climate mitigation potential ranges from 0.5261 to 0.6394 tons $\mathrm{CO}_{2}$ equivalent per acre per year in the first 10 years (Ryals et al. 2015), and declines by approximately half of that by year 30 . Applying organic materials to rangelands in Southern California demonstrated co-benefits: stabilizing soil nitrogen stocks, improved plant community resilience and productivity, and increased soil organic matter after 1 year of application (Zink and Allen 1998). However, due to the very limited number of studies and the need to demonstrate sustained carbon sequestration, long-term studies (greater than 10 years) that span California rangelands are needed to validate these results and provide longterm policy recommendations. Climatic variation
Restoration of native oaks and woody riparian areas on rangelands offers opportunities for increasing carbon storage in these systems.

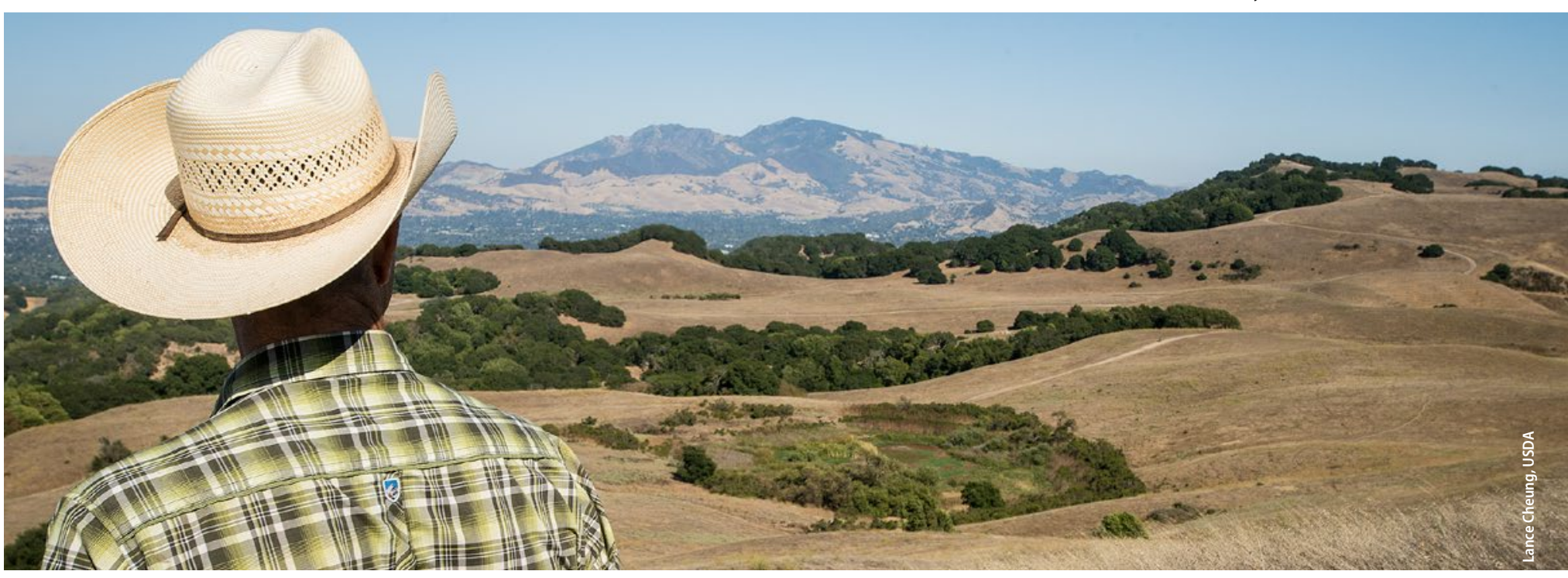




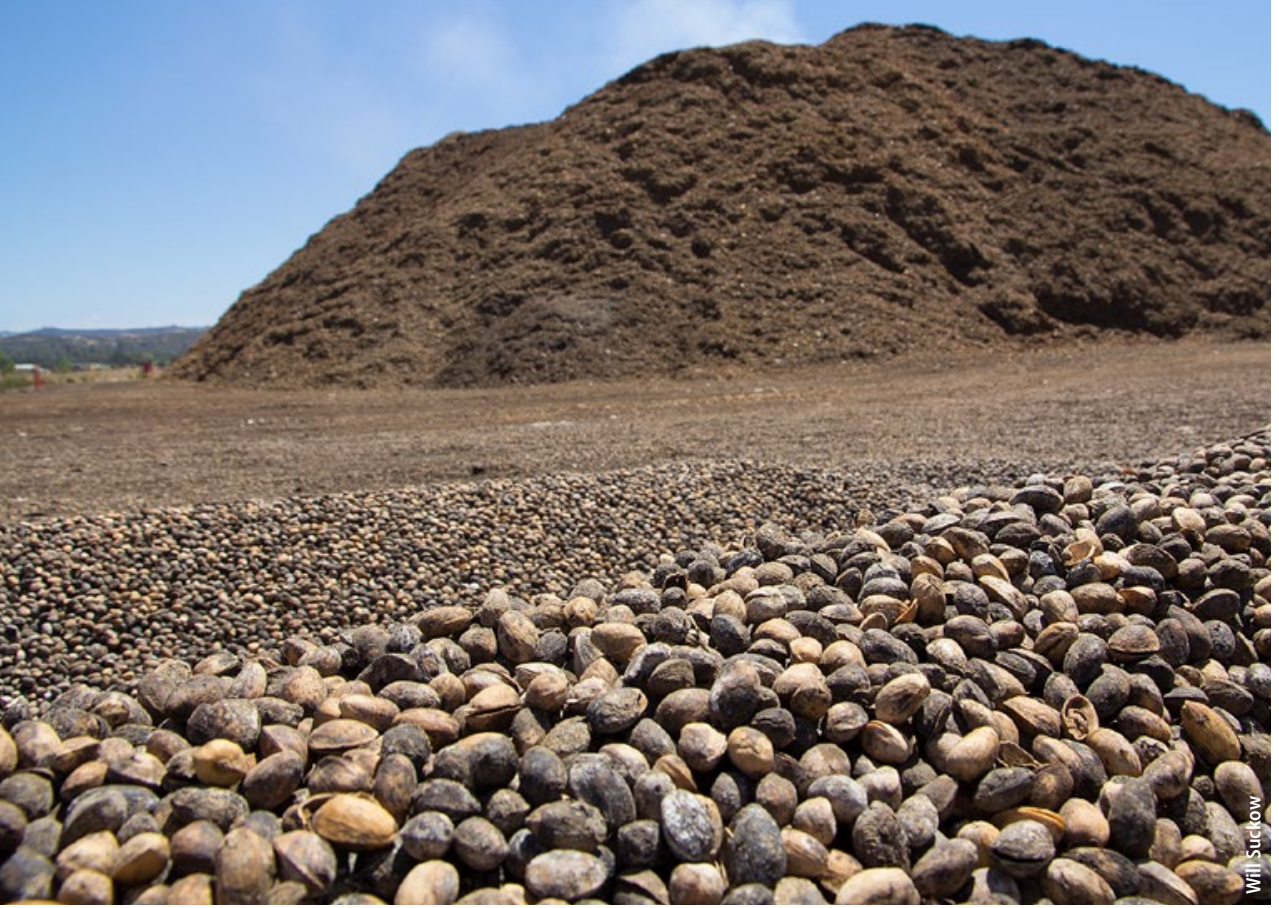

Currently, biomass energy production in California from agricultural residues - such as pistachio shells (foreground) and wood chips (background) - is largely based on the combustion of material from orchards and vineyards. Because biomass-based energy is more expensive than other renewable sources, policy changes or incentives are needed to expand this sector. carbon sequestration benefits. Further, it will be im- across the state may enhance or diminish observable portant to ensure that rangeland compost application practices do not lead to undesired plant species shifts and do not create negative trade-offs for water quality through nutrient run-off or leaching; it will also be important to track emissions associated with fossil fuel use for transportation and distribution of compost across rangeland sites.

Additional practices that have shown benefit elsewhere and should be examined in California include planting of legumes, fertilization, irrigation and grazing management. In particular, grazing management may significantly impact rangeland carbon sequestration. While heavy grazing that leads to erosion can degrade carbon storage, there is conflicting evidence in California and elsewhere on specific grazing practices that can benefit soil carbon (DeLonge et al. 2014). Most studies in California that have assessed the effects of grazing on soil carbon compared only grazed versus ungrazed (e.g., Silver et al. 2010), without assessing the effects of grazing duration, intensity, frequency and rest periods.

The USDA Natural Resources Conservation Service provides cost-share programs for range managers to split the cost of implementing improved management techniques. Currently, only $30 \%$ to $40 \%$ of California ranchers participate in these programs (Lubell et al. 2013). The research above points to the magnitude of opportunity from alternative rangeland practices and the need to identify socioeconomic opportunities and barriers to greater participation in range management incentive programs.

\section{Biomass-based energy production}

The most recent assessment of biomass in California details the availability of resources, including agricultural biomass, among others, that could support generation of three to four times the current biomass-based renewable energy being produced, depending on policies and regulations affecting biomass use (California Biomass Collaborative 2015). Biomass use for energy, however, has declined in recent years, as it is generally more expensive than alternative fuels. In addition, interconnection issues between biomass facilities, such as anaerobic digesters, and utilities complicate and increase the cost of new facilities. Research and policy actions to reduce barriers and incentivize co-benefits from the use of biomass for power and fuel will be required to expand this sector sustainably.

Current biomass energy production from agricultural residues in California is largely based on combustion of nut shells and woody biomass from orchards and vineyards. While one grower has installed a successful on-farm small-scale gasification systems for nut shells and wood chips, larger scale facilities that convert woody biomass to electricity are typically more than 40 years old, and the power produced is more expensive than other forms of alternative energy. Many plants are now idle or closed, leaving tree and vine producers with few or more expensive options for disposal of biomass.

Other underutilized agricultural biomass includes rice straw and livestock manures suitable for anaerobic digestion technology (Kaffka et al. 2012 and 2016). Manure alone is not a high biogas-yielding feedstock. Supplementing manure with fermentable feedstocks such as crop or food processing residues (Amon et al. 2011) can improve the energy and economic return from anaerobic digesters (Kaffka et al. 2016), but this practice currently faces regulatory and practical obstacles, like managing an additional source of organic materials and additional nutrients and salts. Nonetheless, there is limited, but real potential for some crop-based biofuels and bioenergy in California based on locally optimal feedstocks and biorefineries (Jenkins et al. 2009; Kaffka et al. 2014).

\section{Priorities for future research}

Here we identify cross-cutting priorities that will enable scaling and, equally important, the integration of multiple practices to achieve more substantial progress toward both climate change mitigation and adaption in agriculture. Among the priorities we identify are:

- Replication and longer-term studies to quantify the GHG mitigation or carbon sequestration associated with specific practices.

- Quantification of synergies from stacking multiple practices over time and scale (e.g., field to region) 
to address efficacies for carbon sequestration, emissions reductions and nitrogen use.

- Characterization and, where possible, quantification of co-benefits (water, economic, air quality) from soil management practices, livestock grazing and manure management, and biomass-based fuels.

- Using social and political science research to identify socioeconomic factors that either create barriers or promote adoption of practices (e.g., social networks, gender, social norms, and values).

- Validation of metrics for soil health parameters, including calibration of models for California conditions that may be used to estimate metrics, such as:

- Potential use of remote sensing to measure adoption of specific practices outlined above.

- Validation and/or calibration of models for estimating GHG emissions, including the crop and soil process model, DAYCENT (Del Grosso et al. 2005), and the USDA's whole farm and ranch carbon and GHG accounting system, which uses the DAYCENT model (COMET-Farm; http://cometfarm.nrel.colostate.edu/).

- Research into the design of incentives (such as payments, tax credits, low interest loans, etc.) to leverage private investment and promote adoption of emissions-reduction practices in agriculture.

- Development of metrics and sampling or survey tools to assess adoption of emissions-reduction practices.

- Development of farmer demonstration and evaluation networks for scaling up the adoption of improved performance systems.
As this report outlines, the practices and technologies that can assist California to meet its climate change goals are as diverse as the types of agricultural practices across the state. Support for research within California agro-climactic contexts has been critical to identifying these climate strategies. Similarly, state incentive programs are critical to promoting adoption of these practices at scale through co-investment with the agriculture sector to achieve the goal of sustaining a vibrant food system for our state and nationally. CA

R. Byrnes is Junior Specialist and V. Eviner is Associate Professor in the Department of Plant Sciences at UC Davis; E. Kebreab is Professor in the Department of Animal Science at UC Davis; W.R. Horwath is Professor of Soil Biogeochemistry and J.G. Boswell Endowed Chair in Soil Science and L. Jackson is Professor and UC Cooperative Extension (UCCE) Specialist in the Department of Land, Air and Water Resources at UC Davis; B.M. Jenkins is Professor in the Department of Biological and Agricultural Engineering at UC Davis; S. Kaffka is UCCE Specialist in the Department of Plant Sciences at UC Davis; A. Kerr was formerly a Program Coordinator at USDA Southwest Regional Climate Hub, Davis; J. Lewis is formerly with the World Food Center at UC Davis and now Associate Vice President for Agricultural Sustainability at the Environmental Defense Fund, Sacramento; F. Mitloehner is Professor and UCCE Specialist in the Department of Animal Science at UC Davis; J.P. Mitchell is UCCE Cropping Systems Specialist in the Department of Plant Sciences at UC Davis; K.M. Scow is Professor in the Department of Land, Air and Water Resources at UC Davis; K.L. Steenwerth is Soil Scientist, USDAARS, Davis; and S. Wheeler is Professor in the Department of Human Ecology at UC Davis.

\section{References}

Amon R, Jenner MW, El Mashad $H$, et al. 2011. California's Food Processing Industry: Organic Residue Assessment. California Energy Commission. Draft Report: PIER contract 500-08-017. http://biomass. ucdavis.edu/files/2013/09/09 20-2013-2011-05-pier-foodresidues-final-report.pdf.

Bowles TM, Raab PA, Jackson LE. 2015. Root expression of nitrogen metabolism genes reflects soil nitrogen cycling in an organic agroecosystem. Plant Soil 392:175-89.

Brennan EB, Acosta-Martinez V. 2017. Cover cropping frequency is the main driver of soil microbial changes during six years of organic vegetable production. Soil Biol Biochem 109:188-204.
Brown P, Muhammad S. 2011 Constraining GHG Emissions from Almond Orchards for Two Nitrogen Fertilizer Sources and Three Microirrigation Systems. Almond Board of California 2010-2011 Annual Research Report. 19 p. http://bit.ly/2qYg8DS Burger $M$, Jackson LE, Lundquist EJ, et al. 2005. Microbial responses and nitrous oxide emissions during wetting and drying of organically and conventionally managed soil under tomatoes. Biol Fert Soils 42:109-18.

Burger M, Venterea RT. 2011. Effects of nitrogen fertilizer types on nitrous oxide emissions. ACS Symposium Series, vol. 1072. American Chemical Society.

Burger M, Horwath WR. 2012. Assessment of Baseline Nitrous Oxide Emissions in California Cropping Systems. California Air Resources Board Contract No. 08-324.
[CARB] California Air Resources Board. 2016. Proposed ShortLived Climate Pollutant Reduction Strategy. 133 p. www.arb ca.gov/cc/shortlived/meetings/04112016/proposedstrategy.pdf.

CARB. 2017a. California GHG Inventory for 2015 - by Category as defined in the Scoping Plan. Updated June 6, 2017. www.arb. ca.gov/cc/inventory/data/data. htm (accessed July 27, 2017).

CARB. 2017b. The 2017

Climate Change Scoping Plan Update: The proposed strategy for achieving California's 2030 greenhouse gas target. www.arb.ca.gov/cc/ scopingplan/2030sp_pp_final. pdf (accessed April 13, 2017).

CA Biomass Collaborative. 2015 An Assessment of Biomass Resources in California, 2013. 60 p. http://biomass.ucdavis. edu/files/2015/04/CA_Biomass_Resource_2013Data CBC_Task3_DRAFT.pdf.
Cameron DR, Marty J, Holland RF, 2014. Whither the rangeland?: Protection and conversion in California's rangeland ecosystems. PLOS ONE 9(8): e103468. doi:10.1371/journal. pone.0103468

Del Grosso SJ, Mosier AR, Parton WJ, Ojima DS. 2005. DAYCENT model analysis of past and contemporary soil N2O and net greenhouse gas flux for major crops in the USA. Soil Tillage Res 83:9-24.

DeLonge MS, Ryals R, Silver WL. 2013. A lifecycle model to evaluate carbon sequestration potential and GHG dynamics of managed grasslands. Ecosystems 16:962-79.

[DOC] Department of Conservation. 2016. California Farmland Conversion Summary. www. conservation.ca.gov/dlrp/ fmmp/trends/Pages/FastFacts. aspx.
Garland GM, Suddick E, Burger $M$, et al. 2011. Direct N2O emissions following transition from conventional till to no-till in a cover cropped Mediterranean vineyard (Vitis vinifera). Agr Ecosyst Environ 144:423-28.

Guerra B, Steenwerth K. 2011. Influence of floor management technique on grapevine growth, disease pressure, and juice and wine composition: A review. Am J Enol Vitic 63(2):149-64.

Gurr GM, Wratten SD, Luna JM. 2003. Multi-function agricultural biodiversity: Pest management and other benefits. Basic Appl Ecol 4:107-16.

Haden VR, Dempsey M, Wheeler $\mathrm{S}$, et al. 2013. Use of local GHG inventories to prioritize opportunities for climate action planning and voluntary mitigation by agricultural stakeholders in California. J Environ Plann Man 56:553-71. 
Hodson AK, Ferris $\mathrm{H}$, Hollander AD, Jackson LE. 2014. Nematode food webs associated with native perennial plant species and soil nutrient pools in California riparian oak woodlands. Geoderma 228-229:182-91.

Hodson AK, Lewis EE. 2016. Managing for soil health can suppress pests. Calif Agr 70(3):137-41. doi:10.3733/ ca.2016a0005.

[IPCC] Intergovernmental Panel on Climate Change. 2006. 2006 IPCC Guidelines for National Greenhouse Gas Inventories. Hayama, Japan: Institute for Global Environmental Strategies. www.ipcc-nggip.iges.or.jp/ public/2006gl/.

Jackson LE, Haden VR, Hollander AD, et al. 2012. Adaptation Strategies for Agricultural Sustainability in Yolo County, California. California Energy Commission. Publication number: CEC-5002012-032.

Jenkins BM, Williams RB, Parker $\mathrm{N}$, et al. 2009. California biomass resources, potentials, logistics, and current uses. Calif Agr 63(4):168-77.

Kallenbach CM, Rolston DE, Horwath WR. 2010. Cover cropping affects soil $\mathrm{N} 2 \mathrm{O}$ and $\mathrm{CO} 2$ emissions differently depending on type of irrigation. Agr Ecosyst Environ 137:251-60

Kaffka S, Barzhee T, El-Mashad H, et al. 2016. Evaluation of Dairy Manure Management Practices for GHG Emissions Mitigation in California. Final Report to the State of California Air Resources Board. http://biomass.ucdavis. edu/publications/.

Kaffka S, Jenner M, Liles G, et al. 2012. Biomass Management Zones and New Pathways to Bioenergy. Draft Report. California Energy Commission, publication no. CEC-500-2012-004. http://biomass.ucdavis.edu/ files/2013/09/09-20-2013-201201-biomass-managementzones-and-new-pathways-tobioenergy.pdf.

Kaffka S, Yeo B-L, Jenner M, et al. 2014. An Integrated Assessment of Agricultural Biomass Derived Alternative Fuels and Power in California. DRAFT project report, California Energy Commission. Contract CEC-500-01-016. 207 p. http://biomass.ucdavis.edu/ publications/.

Kennedy T, Decock C, Six J. 2013. Assessing drivers of $\mathrm{N} 2 \mathrm{O}$ production in California tomato cropping systems. Sci Total Environ 465:36-47.

Koteen LE, Baldocchi DD, Harte J. 2011. Invasion of non-native grasses causes a drop in soil carbon storage in California grasslands. Environ Res Lett 6:044001.
Kroeger T, Casey F, Alvarez P, et al. 2009. An economic analysis of the benefits of habitat conservation on California rangelands. Conservation economics white paper. Washington, D.C.: Defenders of Wildlife.

Lewis DJ, Lennox M, O'Geen A, et al. 2015. Creek carbon: Mitigating greenhouse gas emissions through riparian restoration. University of California Cooperative Extension in Marin County. Novato, California. $26 \mathrm{p}$ Lazcano C, Tsang A, Doane TA, et al. 2016. Soil nitrous oxide emissions in forage systems fertilized with liquid dairy manure and inorganic fertilizers. Agr Ecosyst Environ 225:160-72.

Lubell M, Cutts B, Roche LM, et al. 2013. Conservation program participation and adaptive rangeland decisionmaking. Rangeland Ecol Manag 66:609-20.

Ma S, Baldocchi DD, Liukang X. Hehn T. 2007. Inter-annual variability in carbon dioxide exchange of an oak/grass savanna and open grassland in California. Agr Forest Metero 147(3-4):157-71.

Madden NM, Southard RJ, Mitchell JP. 2008. Conservation tillage reduces PM10 emissions in dairy forage rotations. Atmos Environ 42:3795-808.

McSwiney CP, Robertson GP. 2005. Nonlinear response of $\mathrm{N} 2 \mathrm{O}$ flux to incremental fertilizer addition in a continuous maize (Zea mays L.) cropping system. Glob Change Biol 11:1712-19.

Mitchell JP, Pettygrove GS, Upadhyaya S, et al. 2009. Classification of conservation tillage practices in California irrigated row crop systems. UC ANR Publication 8634.

Mitchell JP, Singh PN, Wallender WW, et al. 2012. No-tillage and high-residue practices reduce soil water evaporation. Calif Agr 66(2):55-61.

Mitchell JP, Shrestha A, Mathesius K, et al. 2017. Cover cropping and no-tillage improve soil health in an arid irrigated cropping system in California's San Joaquin Valley, USA. Soil Till Res 165(January):325-35. doi:10.1016/j.still.2016.09.001

Moate PJ, Williams SR, Torok VA, et al. 2014. Grape marc reduces methane emissions when fed to dairy cows. J Dairy Sci 97:5073-87

Moraes LE, Fadel J, Castillo A, et al. 2015. Modeling the trade-off between diet costs and methane emissions: A goal programming approach. J Dairy Sci 98:5557-5571.
Moraes LE, Strathe AB, Fade JG, et al. 2014. Prediction of enteric methane emissions from cattle. Glob Change Bio 20:2140-2148

Morandin L, Long RF, Pease C, Kremen C. 2011. Hedgerows enhance beneficial insects on farms in California's Central Valley. Calif Agr 65:197-201.

Niu M, Appuhamy JADRN, Leytem A, et al. 2016. Effect of dietary crude protein and forage contents on enteric methane emissions and nitrogen excre tion from dairy cows simultaneously. Anim Prod Sci 56:312-21.

Owen J, Silver W. 2017. Greenhouse gas emissions from dairy manure management in a Mediterranean environment. Ecol Appl 27:545-59. doi:10.1002/ eap. 1465 .

Parker SS, Schimel JP. 2009. Invasive grasses increase nitrogen availability in California grassland soils. Invas Plant Sci Mana 3:40-7.

Ponisio LC, M'Gonigle LK, Kremen C. 2015. On-farm habitat restoration counters biotic homogenization in intensively managed agriculture. Glob

Change Biol 22:704-15.

Poudel DD, Horwath WR, Lanini WT, et al. 2002. Comparison of soil $\mathrm{N}$ availability and leaching potential, crop yields and weeds in organic, low-input and conventional farming systems in northern California. Agr Ecosyst Environ 90:125-37.

Potthoff M, Jackson LE, Sokolow S, Joergensen RG. 2009. Below and aboveground responses to lupines and litter mulch in a California grassland restored with native bunchgrasses. Appl Soil Ecol 42:124-33.

Rabobank. 2014. Competitive Challenges - Environmental Regulations are Changing the Rules of the Game. 12 p. www. sosukeonline.com/editorun lockedlibrary/doc.php?doc id $=554 \&$ action=inline

Ryals R, Silver WL. 2013. Effects of organic matter amendments on net primary productivity and GHG emissions in annual grasslands. Ecol Appl 23:46-59.

Ryals R, Hartman MD, Parton WJ, et al. 2015. Long-term climate change mitigation potential with organic matter management on grasslands. Ecol App 25:531-45. doi:10.1890/13-

2126.1

Santiago-Juarez B, Moraes LE, Appuhamy JADRN, et al. 2016. Prediction and evaluation of enteric methane emissions from lactating dairy cows using different levels of covariate information. Anim Prod Sci 56:557-64.

Schellenberg DL, Alsina MM, Muhammad S, et al. 2012. Yieldscaled global warming potential from $\mathrm{N} 2 \mathrm{O}$ emissions and $\mathrm{CH} 4$ oxidation for almond (Prunus dulcis) irrigated with nitrogen fertilizers on arid land. Agr Ecosyst Environ 155:7-15.

Silver W, Ryal R, Eviner V. 2010

Soil carbon pools in California's annual grassland ecosys-

tems. Rangeland Ecol Manag

63:128-36.

Six J, Ogle SM, Jay breidt F et al. 2004. The potential to mitigate global warming with no-tillage management is only realized when practiced in the long term. Glob Change Bio 10:155-60.

Smukler SM, Jackson LE, O'Geen AT. 2012. Assessment of best management practices for nutrient cycling: A case study on an organic farm in a Mediterranean-type climate. J Soil Water Conserv 67:16-31.

Smukler SM, Sánchez-Moreno S Fonte SJ, et al. 2010. Biodiversity and multiple ecosystem functions in an organic farmscape. Agr Ecosyst Environ 139:80-97.

Steenwerth $\mathrm{KL}$, Jackson LE, Calderón FJ, et al. 2005. Response of microbial community composition and activity in agricultural and grassland soils after a simulated rainfall. Soil Biol Biochem 37:2249-62.

Steenwerth KL, Jackson LE, Calderón FJ, et al. 2002. Soil microbial community composition and land use history in cultivated and grassland ecosystems of coastal California. Soil Biol Biochem 34:1599-1611.

Steenwerth KL, Strong EB, Greenhut RG, et al. 2015. Life cycle greenhouse gas, energy, and water assessment of wine grape production in California. Int J Life Cycle Ass 20:1243-53.

Suddick EC, Scow KM, Horwath WR, et al. 2010. The potentia for California agricultural crop soils to reduce greenhouse gas emissions: A holistic evaluation. Chapter 4. Donald L. Sparks, editor. Adv Agron 107:123-62.

Suddick EC, Ngugi MK, Paustian K, Six J. 2013. Monitoring soil carbon will prepare growers for a carbon trading system. Calif Agr 67:162-171. 